\title{
Bezpieczeństwo energetyczne Unii Europejskiej a polityka energetyczna Francji i Niemiec
}

\section{Bezpieczeństwo energetyczne współczesnej Europy}

Unia Europejska jest jednym z największych konsumentów energii na świecie. Jej zasoby są ograniczone, tak więc musi polegać na innych państwach, aby zapewnić dostawy surowców energetycznych. Wskutek podjętych różnych działań (m.in. zmniejszenie energochłonności przemysłu, lepsze systemy ociepleń budynków mieszkalnych, ograniczenie strat w sieciach przesyłowych), konsumpcja energii brutto w Unii Europejskiej zmalała w okresie 2006-2012 o 8,1\%. Podczas gdy w 1990 roku zużyto 1670 mln ton tzw. oleju ekwiwalentnego (Mtoe), tak w 2006 roku wskaźnik ten osiagnął rekordową wielkość 1830 Mtoe, aby w 2012 roku spaść do 1680 Mtoe. Najwięksi konsumenci energii w UE to RFN, gdzie w 2012 roku wskaźnik wynosił 319 Mtoe (był to spadek o 9,2\% w stosunku do 2006 roku), Francja 258 Mtoe (-5,3\%), W. Brytania 202 Mtoe (-12,2\%), Włochy 163 Mtoe (-12\%) i Hiszpania 127 Mtoe $(-11,9 \%)$. Na pięć państw przypadło łącznie $64 \%$ całego zużycia energii w UE oraz aż 77\% spadku tego zużycia w okresie 2006-2012 (Eurostat, 2012).

Tymczasem, jednym z wiążących celów Unii Europejskiej jest walka ze zmianami klimatu. Europejska polityka energetyczna dąży do zapewnienia bezpieczeństwa dostaw i utrzymanie przystępnych cen, przy jednoczesnej realizacji celów redukcji emisji gazów cieplarnianych i rozwoju odnawialnych źródeł energii. W świetle ostatnich wydarzeń geopolitycznych, czyli kryzysu na Ukrainie oraz przejściowych zakłóceń w dostawach gazu w 2006 i 2009 roku, w Unii Europejskiej zaistniała pilna konieczność rozwoju nowoczesnej struktury energetycznej, zwiększenie współpracy i uruchomienie wspólnej europejskiej polityki energetycznej. Od tego czasu UE zrobiła wiele, aby wzmocnić bezpieczeństwo energetyczne w zakresie dostaw gazu, koncentrując się w pierwszej kolejności na zwiększeniu dywersyfikacji źródeł dostaw gazu i ropy naftowej. Jednak prace nie sąjeszcze zakończone i niezbędne są dalsze kroki. Na tle rozwoju sytuacji na Ukrainie, Rada Europejska w marcu 2014 r. położyła silny nacisk na bezpieczeństwo energetyczne oraz wezwała Komisję do przygotowania pogłębionej analizy bezpieczeństwa energetycznego. Głównymi dostawcami ropy dla państw UE nadal pozostawały Rosja, kraje OPEC i Norwegia. Węgiel kamienny pochodzi głównie z Rosji, Kolumbii, Afryki Południowej i Stanów Zjednoczonych (Questions and answers, 2014).

Sektor transportu jest największym obszarem zużycia energii w Europie (33\%), następnie mieszkaniowy (27\%), przemysł (24\%), handel (13\%) i rolnictwo (2\%). Zależność UE od importowanej energii od połowy lat dziewięćdziesiątych ubiegłego stulecia 
wykazuje tendencje wzrostowe. Przyjmuje się, że obecnie UE wydaje dziennie ponad 1 mld euro na import surowców energetycznych. To prawie jedna piąta całkowitego przywozu UE. W roku 2012 aż 53\% zużytej w UE energii pochodziło z importu. W szczególności sprowadzono $88 \%$ surowej ropy naftowej, $66 \%$ gazu ziemnego, $42 \%$ z paliw stałych. Mniej niż 4\% pochodziło z odnawialnych źródeł energii. Zależność od odnawialnych źródeł energii jest znikoma i głównie skoncentrowana na biomasie ( $L a$ Commission européenne a proposé une nouvelle stratégie pour la sécurité énergétique, 2014).

Unia Europejska jest silnie uzależniona od importu uranu (95\%) od największych producentów, takich jak Australia i Kanada. Tak więc $34 \%$ energii pochodzi z ropy naftowej i produktów ropopochodnych. UE jest drugim największym konsumentem ropy na świecie po USA. Większość tego surowca (benzyna, olej napędowy) (95\%) jest zużywana w transporcie, $23 \%$ energii pochodzi z gazu. Gaz wykorzystywany jest głównie do ogrzewania i produkcji energii elektrycznej. Prawie 19\% całej energii elektrycznej wytwarzanej w UE pochodzi ze spalania gazu. Sektor mieszkalnictwa i sektor usług zużywa około $40 \%$, podczas gdy przemysł około $25 \%$ zużycia krajowego brutto.

Kolejno $17 \%$ energii pochodzi z paliw stałych. Są to węgiel kamienny, węgiel brunatny i torf. Paliwa stałe są najczęściej wykorzystywane w zakładach produkujących energię elektryczną i ogrzewanie. Następne $13 \%$ energii pochodzi z elektrowni jądrowych. A to zapewnia $27 \%$ energii elektrycznej, w większości wytwarzanej we Francji, Wielkiej Brytanii, Szwecji, Niemczech, Belgii i Hiszpanii. 14\% energii pochodzi z odnawialnych źródeł energii. Prawie połowa $\mathrm{z}$ tego pochodzi z energii wodnej, jedna czwarta to wiatr, biomasa i odpady, a $8 \%$ to energia słoneczna. $24 \%$ energii elektrycznej jest produkowane $\mathrm{z}$ odnawialnych źródeł energii (Eurostat, 2012).

Kwestie ochrony środowiska zajmują coraz większy obszar w debacie na temat polityki energetycznej, ale w tej kwestii opinia publiczna w Niemczech i we Francji pozostaje zróżnicowana w poglądach. Chociaż Niemcy w dużym stopniu i coraz śmielej opowiadają się za energią ze źródeł odnawialnych, to we Francji nadal za główny priorytet uchodzi energia jądrowa. Wydarzenia w elektrowni Fukushima doprowadziły jednakże do zmiany postaw opinii publicznej we Francji w kwestii energetyki jądrowej. Trudno powiedzieć $\mathrm{w}$ jakim stopniu nastroje społeczne w obu państwach będą nadal ewoluować i czy będzie można mówić o coraz to większej zbieżności w poglądach na rozwój polityki energetycznej i konieczność jej uwspólnotowienia w Unii Europejskiej. Jakie są więc wyzwania w realizacji polityki energetycznej w obu państwach, jakie jest podejście Niemiec i Francji do wpływu zmian klimatu na przyrodę i otoczenie człowieka?

\section{Polityka energetyczna Francji i Niemiec}

Nie ulega wątpliwości, iż Francja chlubi się długoletnią tradycją pozyskiwania energii elektrycznej z rudy uranowej. Po II wojnie światowej konsekwentnie postawiła na rozwój energetyki jądrowej, pomimo wstrząsów związanych z rozwojem w Europie Zachodniej w końcu lat siedemdziesiątych XX wieku masowych ruchów ekologicznych. Z jej inspiracji, a konkretnie Jeana Monneta powstała w 1957 r. Europejska 
Wspólnota Energii Atomowej (EURATOM), która jednak nie mogła poszczycić się żadnymi znaczącymi sukcesami w dziedzinie budowy wspólnotowych elektrowni jądrowych. Uruchomienie pierwszego francuskiego reaktora jądrowego Zoé w $1948 \mathrm{r}$. wywołało ogromny entuzjazm Francuzów. Hasło „La radiance de la France” (określenie dwuznaczne, mogące oznaczać zarówno blask chwały Francji, jak i promieniowanie radioaktywne) stało się popularnym sloganem politycznym. O słuszności postawienia na energetykę jądrową Francja utwierdziła się w 1973 roku, kiedy doszło do kolejnego konfliktu izraelsko-arabskiego i tzw. wojny Jom Kippur, kiedy to cena ropy wzrosła czterokrotnie. Uderzyło to w wiele państw, m.in. we Francję, która z jeszcze większą determinacją zaczęła budować reaktory atomowe (plan Messmera) i tym samym zmniejszała swoją zależność od surowców kopalnianych (Biberian, 2011). Podjęte działania przyniosły szybkie efekty, obecnie Francja szczyci się największym parkiem reaktorów w elektrowniach jądrowych w Europie i jest ważnym eksporterem energii elektrycznej do wielu państw.

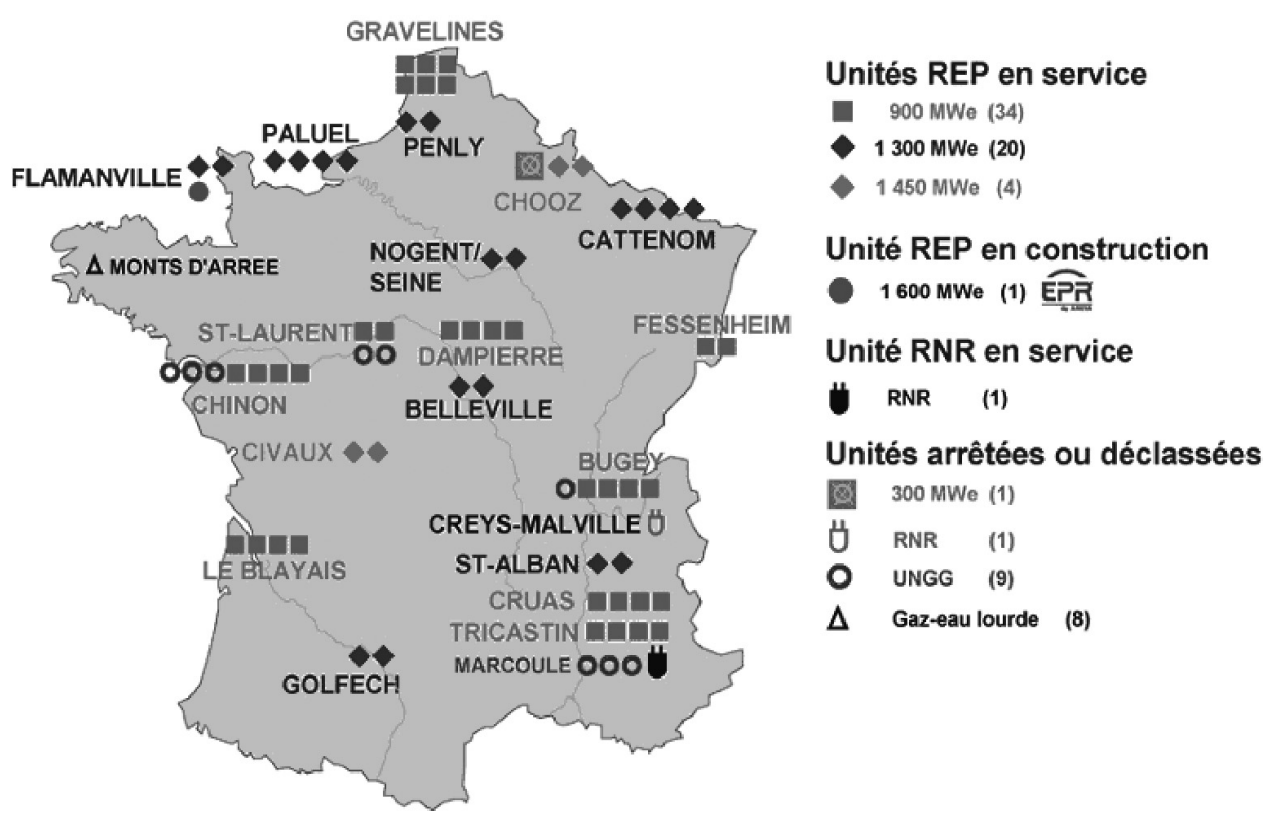

Grafika 1. 58 reaktorów w pracy i jeden w budowie:

- 34 reaktorów o mocy 900 MW uruchomionych pomiędzy 1974 r. i 1976 r.;

- 20 reaktorów 1300 MW oddanych do użytku w latach 1977-1982;

-4 reaktory 1450 MW włączone do pracy pomiędzy 1984 r. i 1991 r.;

- 1 reaktor $1650 \mathrm{MW}$ włączony do sieci w $2007 \mathrm{r}$.

Źródło: Pourquoi autant de nucléaire en France?, http://www.areva.com/group/liblocal/docs/Guide-AREVA/pourquoi-autant-de-nucleaire-en-France.html.

Z drugiej strony choć niskie ceny elektryczności są do dziś pierwszorzędną przesłanką przemawiającą za wykorzystaniem energii jądrowej we Francji, to już argument o niezależności energetycznej był i jest bardziej wątpliwy. Mimo że energia jądrowa zapewnia blisko $75 \%$ w miarę taniej elektryczności, to stanowi tylko $17 \%$ końcowego 
zużycia energii we Francji. Na ogół też podnosi się fakt prawie stuprocentowej zależności Francji od dostaw rudy uranowej, m.in. z Kanady, Nigru czy Australii (Nowak, 2014).

Czy zatem Francja mogłaby zrezygnować z energetyki jądrowej? Odpowiedzi są pozytywne i jako przykład wskazuje się Niemcy, które stopniowo odchodząc od tradycyjnych surowców energetycznych, pozostają eksporterem netto energii elektrycznej. Francja mogłaby podążyć ich śladem, choć ma świadomość, że odchodzenie od energetyki jądrowej będzie długotrwałym procesem obliczonym na kilka dekad. Towarzyszyć będzie temu nieuchronny wzrost cen w dostawach dla konsumentów, gdyż obecnie pozyskiwany prąd elektryczny z reaktorów atomowych jest stosunkowo tani (Demesmay, Marchetti, 2010, s. 7-9).

Energia jądrowa ma wiele zalet i łatwo może zastąpić niedobór przyszłych rezerw ropy, gazu i węgla. Paliwa kopalne, które stanowią obecnie ponad 4/5 energii pierwotnej na świecie wyczerpują się w szybkim tempie, a nowe pokłady i złoża stają się coraz mniej dostępne i trudniejsze w eksploatacji (Młynarski, 2013, s. 56-69). Elektrownia jądrowa jest pożyteczna, ponieważ jest ona w stanie produkować w sposób ciagły ogromne ilości energii elektrycznej w przeciwieństwie do energii odnawialnej. Energia wiatrowa i słoneczna, którą zamierza się rozwijać, posiadają z pewnością zalety, ale także i ograniczenia. Mają one niską wydajność, nie jest to energia trwale dostępna. Tak więc nigdy nie można być pewnym, że w sytuacji kiedy będzie konkretne olbrzymie zapotrzebowanie na prąd elektryczny, to instalacje wiatrowe i słoneczne nie zawioda. Na tym tle jaskrawiej uwidaczniają się pozytywne strony energii jądrowej.

Innym ważnym powodem przemawiającym za wykorzystaniem energii jądrowej sąjej walory ekologiczne: w przeciwieństwie do paliw kopalnych jest to produkcja praktycznie bez emisji gazów cieplarnianych $\left(\mathrm{CO}_{2}\right)$. Jest zatem ona cennym instrumentem niezbędnym do walki z groźbą globalnego ocieplenia. Do tych dwóch argumentów można dodać trzeci: konkurencyjność gospodarcza, ponieważ koszt wytwarzania energii elektrycznej z atomu jest stosunkowo niski (Société Française d'Energie Nucléaire, 2013).

Tabela 1

Produkcja i zużycie energii elektrycznej we Francji (2000-2013) w gigawatogodzinach mln kilowatogodzinach)

\begin{tabular}{||l|r|r|r|r|r|r||}
\hline & \multicolumn{1}{|c|}{$\mathbf{2 0 0 0}$} & $\mathbf{2 0 0 5}$ & $\mathbf{2 0 1 0}$ & $\mathbf{2 0 1 1}$ & $\mathbf{2 0 1 2}$ & $\mathbf{2 0 1 3}$ \\
\hline Jądrowej & 395200 & 429980 & 407880 & 421070 & 404880 & 403700 \\
\hline Paliw kopalnych & 49880 & 59650 & 59480 & 51260 & 47970 & 44700 \\
\hline Hydrauliczne & 71590 & 56180 & 67600 & 50290 & 63820 & 75720 \\
\hline Inne odnawialne & 0 & 4320 & 15260 & 19300 & 24720 & 26820 \\
\hline - Lacznie z wiatru & 0 & 980 & 9720 & 11940 & 14870 & 15890 \\
\hline - Eacznie słoneczna & 0 & 0 & 570 & 2400 & 4000 & 4640 \\
\hline Całkowitej produkcji & 516670 & 550130 & 550220 & 541910 & 541390 & 550950 \\
\hline Bilans import-eksport & -69480 & -60330 & -30510 & -56880 & -45160 & -48830 \\
\hline Pompowanie & -6600 & -6590 & -6500 & -6830 & -6710 & -7130 \\
\hline Zużycie brutto & 440590 & 483210 & 513210 & 478200 & 489520 & 494980 \\
\hline Straty linii & -29920 & -31710 & -37090 & -34900 & -34320 & -34880 \\
\hline Zużycie netto & 410670 & 451500 & 476120 & 443300 & 455200 & 460100 \\
\hline \hline
\end{tabular}

Źródło: RTE - Roczne statystyki 2010, bilans 2011-2013. 
Energia ze źródeł odnawialnych we Francji

Warto podkreślić, iż odnawialne źródła energii zajmują coraz więcej miejsca w debacie publicznej we Francji, co przekłada się na zachowania i deklaracje polityków. Już w 2012 r. w pierwszych miesiącach swojego urzędowania w Pałacu Elizejskim, prezydent François Hollande zapowiedział, iż nastąpi redukcja udziału energii jądrowej w ogólnym bilansie energii do 2025 roku z $80 \%$ do $50 \%$. Na ogół podkreśla się, że Francja posiada najlepsze warunki dla produkcji energii odnawialnej w przeliczeniu na jednego mieszkańca (oszacowane przez holenderski organ planowania; biomasa, woda i promieniowanie słoneczne). Niestety, niezbyt dobrze to wygląda w praktycznym zastosowaniu i działaniu. W 2010 roku planowano już 10\% zużycie tejże energii, ale założone progi nie zostały osiagnięte ze względu na procedury licencyjne i długotrwałe postępowanie administracyjne. Udział energii ze źródeł odnawialnych w państwowym bilansie energetycznym wyniósł zaledwie 7,9\% (2011), ale w następnych latach odnotowano zauważalny przyrost: $\mathrm{w} 2012 \mathrm{r}$. było to $16,3 \%$. W europejskim zestawieniu jest to udział stosunkowo wysoki, ale obecny boom w dziedzinie energii słonecznej i wiatrowej już takiej dynamiki we Francji nie pokazuje (Aykut, 2013, s. 5-6; SOeS, 2012, s. 28).

W 2007 roku po wyborze Nicolasa Sarkozy'ego na prezydenta państwa francuskiego we wrześniu i grudniu odbyły się liczne spotkania i panele dyskusyjne (tzw. Grenelle de l'Environnement) w celu podjęcia działań dotyczących zrównoważonego rozwoju sprzyjającego środowisku naturalnemu. Zamierzano stworzyć regionalne wzorce spójności ekologicznej poprzez redukcję emisji gazów cieplarnianych i poprawę efektywności energetycznej. Kampanią kierował ówczesny minister ds. środowiska Jean-Louis Borloo i udało mu się pod wspólnymi hasłami ekologicznymi zjednoczyć różne środowiska polityczne i proekologiczne. W efekcie w Zgromadzeniu Narodowym w październiku 2008 r. uchwalono pakiet Grenelle I, a w lipcu 2010 r. ustawę Grenelle II z zasadniczym celem zwiększenia do $23 \%$ stopnia zużycia odnawialnych źródeł energii do roku 2020. Założenie to wydawało się być ambitne, ale nie można zapominać, że Francja $\mathrm{w}$ ramach negocjacji w sprawie pakietu energetyczno-klimatycznego zobowiązała się nadrobić istniejące zaległości i wyrównać do europejskich partnerów, zwłaszcza Niemiec (Vannier, 2008, s. 13-14). Niestety, kadencja Sarkozy’ego pod wieloma względami okazała się niezbyt udana i zakończyła się serią niepowodzeń m.in. w polityce i ochrony środowiska, w tym również w dziedzinie odnawialnych źródeł energii (Aykut, 2013, s. 10-11).

Będące do dyspozycji dane statystyczne i badania z 2013 r. potwierdziły, że stan francuskiej polityki energii odnawialnej z pewnością nie napawał optymizmem. $\mathrm{Na}$ ogół w środkach masowego przekazu podkreślało się, że osiagnięcie $23 \%$ progu zużycia energii odnawialnej w 2020 roku nie będzie możliwe do osiągnięcia bez znacznych dodatkowych wysiłków i nakładów finansowych.

W 2012 roku z wyborów prezydenckich zwycięsko wyszedł François Hollande z ważnymi obietnicami zmniejszenia udziału energii jądrowej w ogólnym bilansie państwa do 2020 roku o 50\%. Zgodnie z obietnicą z kampanii wyborczej postanowił przekształcić system energetyczny Francji, zamknąć kilka reaktorów jądrowych (rozpoczynając od pierwszej elektrowni w Fessenheim), zmodernizować istniejące starsze 
instalacje oraz zainwestować w źródła energii odnawialnej. Jednakże już 3 grudnia 2013 r. była prezes koncernu Areva Anne Lauvergeon oznajmiła, że rządowy program jest praktycznie niewykonalny. W odpowiedzi spotkała się z zarzutami o faworyzowanie „przemysłu przeszłości”. Zarzucono jej brak wiary w innowacyjność energetyków francuskich i przekreślanie dotychczasowych znakomitych osiagnięć w dziedzinach najnowszych technologii (np. najnowszej generacji bezpieczny europejski reaktor ciśnieniowy EPR). Generalnie panuje przekonanie, że Francja jest na dobrej drodze do „rewolucji energetycznej”, jednakże dominacja przemysłu atomowego i związanego $\mathrm{z}$ tym lobby jest na tyle silna, że proces ten rozłożony musi być na lata (Le nucléaire français, 2011).

Tabela 2

Miesięczna produkcja energii elektrycznej z odnawialnych źródel energii (GWh) we Francji w 2014 r. (styczeń-wrzesień)

\begin{tabular}{||l|c|c|c|c|c|c||}
\hline \multicolumn{1}{|c|}{2014} & $\begin{array}{c}\text { Hydroener- } \\
\text { getyka }\end{array}$ & $\begin{array}{c}\text { Olej } \\
\text { roślinny }\end{array}$ & Słońce & Biomasa & Ogólem & $\begin{array}{c}\text { \% procent calkowi- } \\
\text { tego zużycia energii }\end{array}$ \\
\hline Styczeń & 6960 & 2180 & 170 & 570 & 9880 & 20,1 \\
\hline Luty & 7020 & 2470 & 250 & 510 & 10250 & 23,2 \\
\hline Marzec & 6960 & 1290 & 530 & 570 & 9350 & 21,8 \\
\hline Kwiecień & 5800 & 1050 & 590 & 500 & 7940 & 21,9 \\
\hline Maj & 6180 & 1530 & 680 & 560 & 8950 & 25,9 \\
\hline Czerwiec & 5030 & 960 & 760 & 500 & 7250 & 22,3 \\
\hline Lipiec & 6170 & 950 & 680 & 560 & 8360 & 24,8 \\
\hline Sierpień & 5300 & 960 & 670 & 550 & 7480 & 24,3 \\
\hline Wrzesień & 3790 & 720 & 630 & 500 & 5640 & 17,0 \\
\hline \hline
\end{tabular}

Źródło: Statistiques RTE consolidées (Réseau de transport de l'électricité, Electricité renouvelable en France -Production hebdomadaire et mensuelle, http://energeia.voila.net/renouv/electricite_renouvelable_france.htm).

W lutym 2013 roku nawiązano współpracę francusko-niemiecką w dziedzinie energii odnawialnej. W opinii prezydenta Hollande'a miało to być przedsięwzięcie na miarę Airbusa. Towarzyszyła temu ożywiona debata społeczna w obu państwach. Wspólny, francusko-niemiecki koncern energetyczny ma być wzorowany na grupie lotniczo-zbrojeniowej Airbus, powstałej w wyniku fuzji aktywów Francji, Niemiec i Hiszpanii. Prezydent Hollande pragnął, aby firmy energetyczne obu krajów połączyły swoje możliwości oraz umiejętności technologiczne i produkcyjne. Spotkanie w sprawie nowego przedsięwzięcia odbyło się 19 lutego 2014 r. w Paryżu. Jego uczestnicy omówili sposoby współpracy Francji i Niemiec w zakresie efektywności energetycznej, magazynowania energii oraz inteligentnych sieci energetycznych. Według źródeł z Pałacu Elizejskiego, F. Hollande rozmawiał na ten temat z kanclerz Niemiec Angelą Merkel podczas jej wizyty w Paryżu w grudniu 2013 r. Przedstawiciel niemieckiego ministerstwa ekonomii, odpowiedzialny za energetykę, oświadczył, że jak najściślejsza współpraca w tej dziedzinie leży w interesie Berlina. W Paryżu powstało specjalne wspólne biuro łącznikowe ds. energii odnawialnej (Dehmer, 2014).

Symbolem zawiązującej się współpracy miał być wybór na partnera dla kontrolowanego przez Francuzów koncernu energetycznego Alstom niemieckiego Siemensa 
zamiast planowanego amerykańskiego giganta General Electric. Jednakże dość niespodziewanie i jak podejrzewała prasa niemiecka za aprobatą rządu francuskiego i wsparciu prezesa Alstom Patricka Krona w czerwcu 2014 r. na placu boju pozostał ostatecznie General Electric, który został strategicznym partnerem francuskiego przedsiębiorstwa, przy powiększeniu w nim udziałów przez państwo francuskie (Alstom akzeptiert Angebot, 2014; Übernahmeschlacht, 2014; Frankreich unterstützt GE, 2014; Hilfreiche Niederlage, 2014).

Niemiecka polityka energetyczna przyjmowana jest we Francji z mieszanymi uczuciami. Podziwia się Niemców za determinację, jaką wykazują w forsowaniu energii odnawialnej, ale jednocześnie podkreślane są różnice dzielące Francję i Niemcy. We Francji istnieje wciąż przekonanie, że ze względu na znacznie niższą emisję gazów cieplarnianych rząd i społeczeństwo nie muszą podejmować tak radykalnych działań i rozwiązań. Francja pokazuje, że jednak wiele robi w tej dziedzinie, czego przykładem są ambitne plany rozbudowy m.in. elektrowni pływowych u wybrzeży Bretanii i Normandii. Specjaliści na ogół podkreślają, że kooperacja francusko-niemiecka w tym zakresie powinna być bardziej zaawansowana, ale też i doceniają podejmowane próby (Demesmay, Koopmann, Thorel, 2013).

\section{Energia ze źródeł odnawialnych w RFN}

Gotowość Niemiec do działań na rzecz zastosowania energii odnawialnej i poszukiwanie trwałych rozwiązań w tej kwestii nie są nowe. Już w latach 1990 i 2001, zużycie energii pierwotnej w Niemczech spadało średnio o 0,3\% rocznie, a emisja gazów cieplarnianych o 2,1\%. Warto podkreślić, że pierwsze kroki w celu stopniowego wycofywania elektrowni jądrowych podjęto już w 2000 roku (Marcel, 2011). W kolejnych latach (1998-2000), Niemcy zainwestowały ponad miliard euro w różne sektory rozwoju odnawialnych źródeł energii. W 2002 roku Niemcy przekroczyły etap 10000 MW z zainstalowanych elektrowni wiatrowych, a była to jedna trzecia światowego potencjału.

W 2000 roku pierwszy w historii rząd federalny koalicji SPD i Zielonych (1998-2002) przyjął program rozbudowy odnawialnych źródeł energii, a w 2002 roku podjął decyzję o wyłączeniu elektrowni jądrowych do 2021 roku. W 2010 roku chadecko-liberalny rząd przedłużył okres użytkowania elektrowni jądrowych do 2036, ale po katastrofie w japońskiej elektrowni jądrowej w Fukushimie w 2011 roku wycofał się z tych planów i utrzymał termin zamknięcia wszystkich reaktorów atomowych do 2022 r. W społeczeństwie, jak i w partiach politycznych panuje zgoda co do tego, że należy przekształcić sektor energetyczny w bardziej wydajny, efektywny, mniej zanieczyszczający atmosferę i oparty na energii odnawialnej (Bajczuk, 2014, s. 12; Ce que cache, 2014).

Ambitny plan Niemiec zakłada pozyskanie w $80 \%$ energii elektrycznej do $2050 \mathrm{r}$. z odnawialnych źródeł. Zobowiązały się również do redukcji swoich emisji gazów cieplarnianych o 21\% już w latach 2008-2012 (Protokół z Kioto), w porównaniu do poziomu z roku 1990 (Molo, 2013, s. 191-192). Cel ten został osiagnnięty (23,6\%), jednakże stwierdzono, że poziom emisji wzrósł o blisko 1,1\% w 2012 roku. Niemcy planują osiagnąć redukcję o co najmniej $40 \%$ emisji gazów cieplarnianych do roku 
2020 (w porównaniu do 1990). W 2012 roku, energia odnawialna dostarczała 11,6\% zużywanej energii pierwotnej. Ponad połowa pochodziła z biomasy. Reasumując, jeśli RFN zamierza odnieść sukces $\mathrm{w}$ rewolucji energetycznej, będzie musiała podjąć działania $\mathrm{w}$ trzech obszarach $\mathrm{tj}$. w przemyśle, transporcie i w obszarze budowlanym. Efektywność energetyczna i odnawialne źródła przyczyniły się do obniżenia emisji w budynkach (o 30\% w latach 1990 i 2013) oraz w przemyśle (32\% - w tym samym okresie). Natomiast pozostają emisje stabilne w sektorze motoryzacyjnym, gdzie nie odnotowano spadku w ostatnich 4 latach. Warto jednak wspomnieć, że niemieckie gospodarstwa domowe w $2013 \mathrm{r}$. zapłaciły za energię elektryczną prawie o 50\% wyższe rachunki niż francuskie.

Wykres 1. Produkcja energii w RFN w 2012 roku

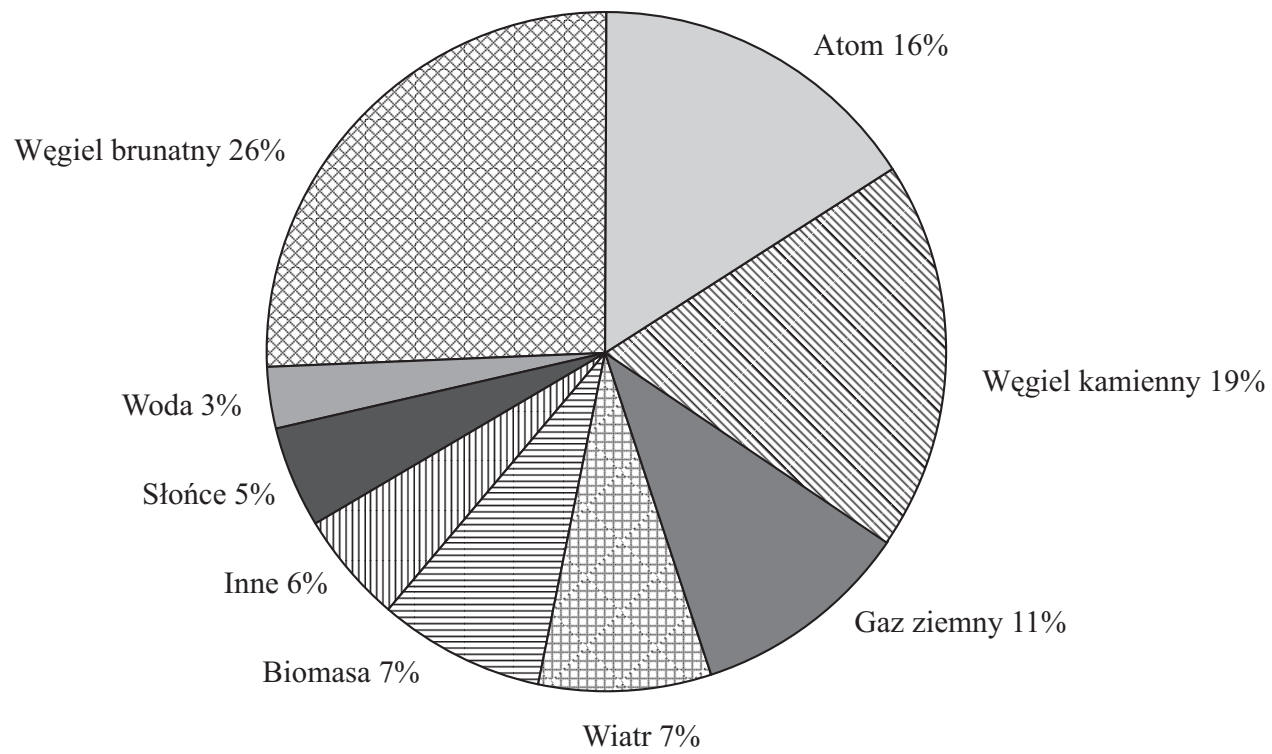

Źródło: Bloomberg New Energy Finance BDEW, http://about.newenergyfinance.com/about/.

Pomiędzy rokiem 2000 i 2013, produkcja prądu elektrycznego z elektrowni jądrowych zmniejszyła się o $43 \%$ przy jednoczesnej redukcji o $2 \%$ z węgla kamiennego i brunatnego. Energii ze źródeł odnawialnych wzrosła o 300\% (pomnożona przez 4,00), a całkowita produkcja wzrosła o 9,9\% (Ce que cache, 2014).

Produkcja energii elektrycznej w Niemczech w latach 2000-2013 [w mln kWh]

\begin{tabular}{||l|c|c|c|c|c|c||}
\hline & $\mathbf{2 0 0 0}$ & $\mathbf{2 0 0 5}$ & $\mathbf{2 0 1 0}$ & $\mathbf{2 0 1 2}$ & $\mathbf{2 0 1 3}$ & Różnica \\
\hline 1 & 2 & 3 & 4 & 5 & 6 & 7 \\
\hline Jądrowej & 169,6 & 163,0 & 140,6 & 99,5 & 97,3 & $-72,3$ \\
\hline Węgiel brunatny + kamienny & 291,4 & 288,2 & 262,9 & 277,1 & 286,0 & $-5,4$ \\
\hline
\end{tabular}




\begin{tabular}{|l|c|c|c|c|c|c||}
\hline \multicolumn{1}{|c|}{1} & 2 & 3 & 4 & 5 & 6 & 7 \\
\hline Olej + gaz & 55,1 & 84,7 & 98,0 & 84,0 & 73,2 & 18,1 \\
\hline Inne & 22,6 & 24,1 & 26,7 & 25,7 & 25,4 & 2,8 \\
\hline Odnawialna & 37,9 & 62,5 & 104,8 & 143,5 & 151,7 & 113,8 \\
\hline Produkcja & 576,6 & 622,6 & 633,0 & 629,8 & 633,6 & 57,0 \\
\hline Zużycie & 579,6 & 614,1 & 615,3 & 606,7 & 599,8 & 20,0 \\
\hline
\end{tabular}

Źródlo: AGEBs - Energiebilanzen AG (2014), http://www.ag-energiebilanzen.de/.

W latach 2006 i 2007, gdy produkcja energii jądrowej spadła o $26 \mathrm{TWh}$, to z węgla kamiennego i brunatnego wzrosła tylko o $8 \mathrm{TWh}$, podczas gdy z odnawialnej wzrosła o 17 TWh. W latach 2010 i 2013 produkcja energii jądrowej spadła o 43 TWh, a z węgla kamiennego i brunatnego wzrosła o $23 \mathrm{TWh}$, z gazu i ropy naftowej spadła o $25 \mathrm{TWh}$, a z odnawialnej wzrosła z $47 \mathrm{TWh}$.

Tabela 4

Udzial każdego źródla energii w produkcji prądu elektrycznego w RFN w latach 2000-2013 [w \%]

\begin{tabular}{||l|c|c|c|c|c||}
\hline & $\mathbf{2 0 0 0}$ & $\mathbf{2 0 0 5}$ & $\mathbf{2 0 1 0}$ & $\mathbf{2 0 1 2}$ & $\mathbf{2 0 1 3}$ \\
\hline Jądrowej & 29,4 & 26,2 & 22,2 & 15,8 & 15,4 \\
\hline Węgiel brunatny+ kamienny & 50,5 & 46,3 & 41,5 & 44,0 & 45,1 \\
\hline ropa + gaz & 9,6 & 13,6 & 15,5 & 13,3 & 11,6 \\
\hline Inne & 3,9 & 3,8 & 4,2 & 4,1 & 4,0 \\
\hline Odnawialna & 6,6 & 10,1 & 16,6 & 22,8 & 23,9 \\
\hline Produkcja & 100 & 100 & 100 & 100 & 100 \\
\hline Zużycie & 100,5 & 98,6 & 97,2 & 96,3 & 94,7 \\
\hline
\end{tabular}

Źródło: AGEBs - Energiebilanzen $A G$ (2014), ibidem.

W roku 2000 węgiel kamienny i brunatny miały udział w produkcji 50,5\% energii elektrycznej w RFN, ale w roku 2013 już tylko 45,1\%. Warto odnotować wzrost udziału pomiędzy rokiem 2010 i 2013 węgla kamiennego i brunatnego w produkcji energii elektrycznej (23 TWh) w przeciwieństwie do ropy i gazu w tych samych latach (25 TWh). Systematycznie także wzrasta energia wyprodukowana ze źródeł odnawialnych.

Większe wykorzystanie węgla niż gazu do produkcji energii elektrycznej, znajduje swoje uzasadnienie w spadku cen światowych węgla (i niskich kosztów $\mathrm{CO}_{2}$ ). Jest to wynik zwiększonego wykorzystania gazu w Stanach Zjednoczonych, przez co jest mniejsze zapotrzebowanie na węgiel, który jest eksportowany do Europy. Jednakże, wykorzystanie węgla powoli odzyskuje swój poziom w amerykańskim wytwarzaniu energii elektrycznej, co zmniejsza możliwości eksportowe. 
Wykorzystanie węgla i gazu w produkcji energii elektrycznej w Stanach Zjednoczonych w latach 2011-2013

\begin{tabular}{|l|c|c|c|}
\hline \multicolumn{1}{|c|}{ USA } & $\mathbf{2 0 1 1}$ & $\mathbf{2 0 1 2}$ & $\mathbf{2 0 1 3}$ \\
\hline Węgiel & $42,3 \%$ & $37,4 \%$ & $39,2 \%$ \\
\hline Gaz & $24,7 \%$ & $30,4 \%$ & $27,4 \%$ \\
\hline \hline
\end{tabular}

Źródło: EIA - Energy Information Administration, styczeń 2014, http://www.eia.gov/todayinenergy/archive.cfm?my=Jan2014.

W 2013 roku, wykorzystanie gazu w produkcji energii elektrycznej w Stanach Zjednoczonych spadło o 9,2\%, a węgla wzrosło o 4,8\% w porównaniu do 2012 r. O ile sprawdzą się prognozy dotyczące energii amerykańskiej przewidujące dalszy wzrost cen gazu w tym państwie, to oznaczać będzie, że mniej węgla będzie dostępnego na eksport do Europy.

W Niemczech początkowo planowano budowę trzydziestu elektrowni cieplnych w latach 2009 i 2017, jednakże od 2007 roku, dwadzieścia dwa projekty zostały porzucone, a cztery zostały przełożone na czas nieokreślony. Kilka projektów planowanych jest po 2020 roku, ale prawdopodobieństwo ich realizacji jest bardzo niskie.

Tabela 6

Planowana redukcja zużycia węgla kamiennego i brunatnego w Niemczech w latach 2015-2035

\begin{tabular}{||l|c|c|c|c|c||}
\hline & $\mathbf{2 0 1 5}$ & $\mathbf{2 0 2 0}$ & $\mathbf{2 0 2 5}$ & $\mathbf{2 0 3 0}$ & $\mathbf{2 0 3 5}$ \\
\hline GW kamienny & 27 & 26 & 21 & 14 & 10 \\
\hline GW brunatny & 20 & 14 & 11 & 9 & 8 \\
\hline TWh kamienny & 140 & 155 & 140 & 90 & 70 \\
\hline TWh brunatny & 130 & 95 & 75 & 65 & 60 \\
\hline
\end{tabular}

Źródło: Allemagne: nucléaire, charbon, renouvelables, http://energeia.voila.net/electri2/allemagne_nucle_charbon.htm.

Szybki rozwój energii ze źródeł odnawialnych do produkcji energii elektrycznej jest głównym czynnikiem stopniowego zaniku znaczenia węgla kamiennego i brunatnego. Pomiędzy rokiem 2000 a 2013, produkcja energii elektrycznej ze źródeł odnawialnych wzrosła z 38 do 152 TWh. Jednocześnie udział energetyki jądrowej spadł ze 170 do 97 TWh. Wielkość zużycia węgla kamiennego i brunatnego (łącznie) spadła nieznacznie, z 291 do $286 \mathrm{TWh}$, podczas gdy całkowita produkcja energii elektrycznej wzrosła o 577-634 TWh.

Podkreśla się że reaktory jądrowe są zbyt drogie i budowa trwa zbyt długo, w porównaniu do innych środków wytwarzania energii elektrycznej, w tym w odniesieniu do nowych odnawialnych źródeł energii. Nie można jednak porównywać kosztów energii elektrycznej wytworzonej w nowej generacji reaktorów, które wejdą w użytkowanie około 2018 i później. Obecny koszt produkcji energii jądrowej wynika raczej z dotychczasowych obliczeń, nie może to jednakże nie uzasadniać budowy nowych reaktorów jądrowych o lepszych parametrach bezpieczeństwa i wydajniejszych. 
Przechodząc do ogólnych wniosków można powiedzieć, że Francja posiada jeden z największych potencjałów do rozwoju energii odnawialnej w Europie, ale jest on hamowany przez interesy przemysłu jądrowego. W Niemczech, znaczenie energii odnawialnej potroiło się w ciagu dekady, głównie tej pochodzącej z wiatru, słońca i biomasy. Pomimo lepszego nasłonecznienia, koszty energii solarnej we Francji są nadal wysokie, w mniej nasłonecznionych Niemczech natomiast dzięki spójnej i wydajnej polityce energetycznej planuje się jej użycie na wielką skalę przemysłową. W RFN energia odnawialna stanowiła już prawie 24\% produkcji energii elektrycznej w 2013 roku, pomimo ograniczonych zasobów wodnych i wiatru, i ogólnym potencjale, który jest niższy niż w słonecznej Francji.

Wydaje się, iż wszystkie scenariusze energetyczne pokazują, iż uwzględnienie trzech działań tj. oszczędność energii, rozwój odnawialnych źródeł energii, energetyki jądrowej, mogą pomóc w zapewnieniu dostaw energii i zachowaniu klimatu naszej planety. Niektóre organizacje podkreślają, iż można obejść się bez energetyki jądrowej; wychodząc z założenia, że odnawialne źródła energii są całkowicie wystarczalne. Nie do końca jest to realne, biorąc pod uwagę techniczne, ekonomiczne i społeczne realia współczesnego świata.

\section{Bibliografia}

AGEBs - Energiebilanzen AG (2014), http://www.ag-energiebilanzen.de/.

Allemagne: nucléaire, charbon, renouvelables, http://energeia.voila.net/electri2/allemagne_nucle_charbon.htm.

Alstom akzeptiert Angebot von General Electric (2014) „Süddeutsche Zeitung” z 21.06.

Aykut S. C. (2013), Ohne Aufwind. Erneuerbare Energien in Frankreich, „DGAPanalyse”, nr 5, August, https://dgap.org/de/article/getFullPDF/24146.

Bajczuk R. (2014), Odnawialne źródła energii w Niemczech. Obecny system rozwoju, grupy interesu $i$ wyzwania, Warszawa, http://www.osw.waw.pl/sites/default/files/raport_oze_pl_net11.pdf.

Biberian J.-P. (2011), L'énergie nucléaire est-elle nécessaire?, „Le Monde” z 1.04.

Bloomberg New Energy Finance BDEW (2012), http://about.newenergyfinance.com/about/.

Ce que cache la baisse de la consommation énergétique en Allemagne (2014), http://www.consoglobe.com/baisse-consommation-energetique-en-allemagne-cg.

Dehmer D. (2014), Für die Franzosen geht um nationale Sicherheit, „Der Tagesspiegel” z 29.04.

Demesmay C., Marchetti A. (2010), Frankreich ist Frankreich ist Europa. Französische Europa-Politik zwischen Pragmatismus und Tradition, „DGAPanalyse”, nr 1, März, https://dgap.org/ de/article/getFullPDF/17822.

Demesmay C., Koopmann M., Thorel J. (2013), Die Konsenswerkstatt Deutsch-französische Kommunikations- und Entscheidungsprozesse in der Europapolitik, w: M. Cruciani, S. von Oppeln, Energiepolitiknach Fukushima - Deutsch-französische Gegensätze und europäische Kompromisse, Baden-Baden.

EIA - Energy Information Administration (2014), http://www.eia.gov/forecasts/aeo/.

Frankreich unterstützt GE bei Alstom-Übernahme (2014), „Handelsblatt” z 20.06.

Hilfreiche Niederlage (2014), ,Süddeutsche Zeitung” z 21.06. 
La Commission européenne a proposé une nouvelle stratégie pour la sécurité énergétique (2014), http://www.europaforum.public.lu/fr/actualites/2014/05/comm-energiestrategie/index.html.

Le nucléaire français, quel avenir? (2011), „Regards sur l'actualité”, août-septembre nr 373.

Marcel V. (2011), Energiesicherheit für Europa, Kernenergie und Erdgas als Brückentechnologien, Baden-Baden.

Młynarski T. ( 2011), Bezpieczeństwo energetyczne w pierwszej dekadzie XXI wieku. Mozaika interesów i geostrategii, Kraków.

Młynarski T. (2013), Francja w procesie uwspólnotowienia bezpieczeństwa energetycznego i polityki klimatycznej Unii Europejskiej, Kraków.

Molo B. (2013), Polityka bezpieczeństwa energetycznego Niemiec w XXI wieku, Kraków.

Nowak Z. (2014), Atomowa duma Francuzów, „Gazeta Wyborcza” z 7.09.

Pourquoi autant de nucléaire en France? (b.d) http://www.areva.com/group/liblocal/docs/Guide-AREVA/pourquoi-autant-de-nucleaire-en-France.html.

Questions and answers on security of energy supply in the EU (2014), European Commission - MEMO/14/379, http://europa.eu/rapid/press-release_MEMO-14-379_en.htm, European Energy Security Strategy, http://ec.europa.eu/energy/security_of_supply_en.htm.

RTE - Roczne statystyki (2010), bilans 2011-2013.

Société Française d'Energie Nucléaire (2013), FRANCE 2013 - LA SFEN DANS LE DEBAT SUR LA TRANSITION ENERGETIQUE, Le nucléaire, énergie utile pour la France...et pour la planète 31 fiches repères pour un débat, http://www.sfen.org/IMG/pdf/fiches_thematiques.pdf.

SOeS, Chiffres clés de l'énergie (2012), http://www.developpement-durable.gouv.fr/IMG/pdf/ Rep_-_Chiffres_cles_energie.pdf.

Statistiques RTE consolidées (Réseau de transport de l'électricité) (2014), Statistiques RTE consolidées (Réseau de transport de l'électricité, Electricité renouvelable en France - Production hebdomadaire et mensuelle, http://energeia.voila.net/renouv/electricite_renouvelable_france.htm).

Übernahmeschlacht: Alstom-Chef hat „Deutschland und Siemens bekämpft” (2014) „Der Spiegel” z 23.06 .

Vannier S. (2008), Herausforderung Klimawandel. Frankreich und Deutschland suchen nach Lösungen, „Dokumente. Zeitschrift für den deutsch-franzősischen Dialog”, nr 5.

\section{Streszczenie}

W 2014 r. prezydent Francji François Hollande zapowiedział pogłębienie współpracy w zakresie energii odnawialnej z Niemcami. Obecnie sektor energetyczny tych państw znacząco się zmienił. Wprowadzona przez rząd Angeli Merkel reforma energetyczna zakłada zwiększenie potencjału odnawialnych źródeł energii do $80 \%$ - do 2050 roku. Z kolei francuska energetyka w $75 \%$ oparta jest nadal na energii atomowej. W planach jest jednak zmniejszenie udziału energii jądrowej o 25\% do 2025 roku. Pomimo różnic, Francja i Niemcy stanowią jeden z najsilniejszych „sojuszy energetycznych” wśród państw członkowskich i znacząco wpływają na politykę energetyczną całej Unii Europejskiej.

Słowa kluczowe: bezpieczeństwo energetyczne, Unia Europejska, Francja, Niemcy, polityka energetyczna 


\title{
European Union energy security French and German energy policy
}

\begin{abstract}
Summary
In 2014 the president of France, François Hollande promised to deepen cooperation in the field of renewable energy with Germany. Currently, the energy sector of these countries has changed significantly. Introduced by the government of Angela Merkel's energy reform envisages increasing the potential of renewable energy sources to $80 \%$ until 2050 , where the French power in the $75 \%$ is still based on atomic energy. However in the plan is to reduce the share of nuclear energy about $25 \%$ until 2025. Despite the differences, France and Germany are one of the strongest "energy alliances" between Member States and significantly affect the energy policy of the European Union as a whole.
\end{abstract}

Key words: energy policy, European Union, France, Germany, energy security 
